\title{
Life Skills in a Minute: Threading a Needle ${ }^{1}$
}

\author{
Heather Janney ${ }^{2}$
}

Threading a needle may sound simple, but is it? A lot of people don't know how. Does the needle scare them? Did they never learn? Can they not see well enough to thread it? So many questions! There are a few different ways to thread a needle, all of which are appropriate.

\section{The Old-Fashioned Way}

\section{Supplies}

- Needle

- Spool of thread

- Scissors

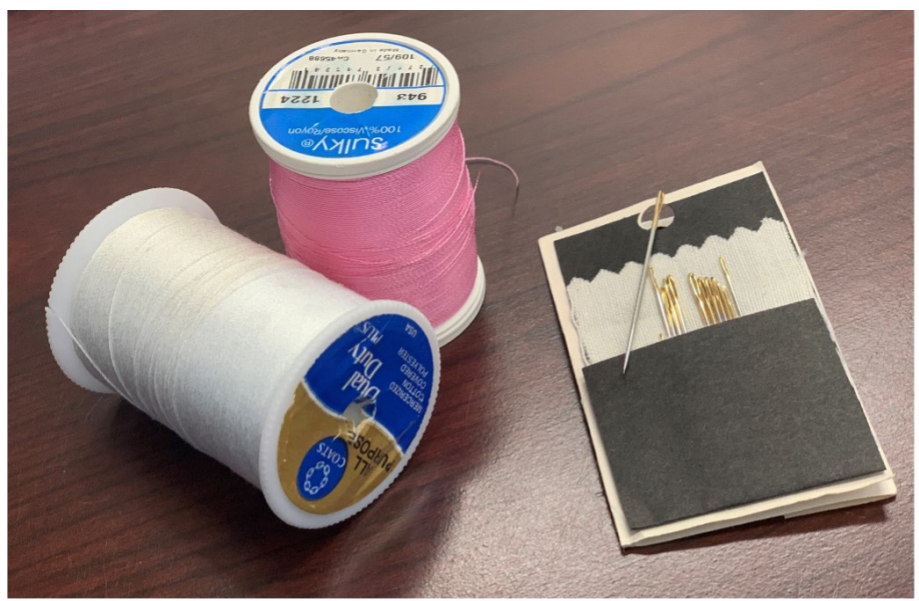

Figure 1. All you need is thread and a needle.

Credits: Heather Janney, UF/IFAS

The old-fashioned way is the easiest and can simplify things so much. You will need a spool of thread and a needle. Cut a piece of thread large enough to loop it through the needle and back. Sixteen inches of thread makes for a manageable size. Once you have pulled the thread out and cut it, put the end still attached to the spool into the notch on the side to keep it from unraveling. Take the piece of thread you cut and push it through the eye of the needle. You may also chooseto trim the end of the thread so that it is angled and no errant "fuzz" hinders threading.

\section{Using a Needle Threader}

A needle threader is included in most sewing kits. It resembles a flattened coin. Cut the thread the same as described earlier.

Push the little metal loop of the threader through the eye of the needle. Insert the thread through the loop, and pull the needle threader back out of the eye of the needle. The thread will come with the needle threader, and your needle is now threaded.

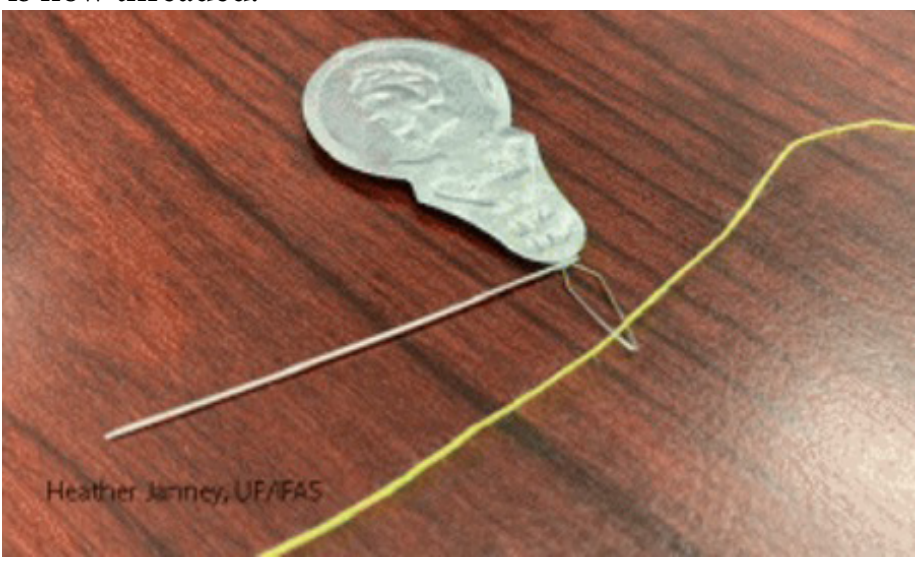

Figure 2. A needle threader. Credits: Heather Janney, UF/IFAS

1. This document is $4 \mathrm{H} 413$, one of a series of the 4-H Youth Development Department, UF/IFAS Extension. Original publication date August 2021. Visit the EDIS website at https://edis.ifas.ufl.edu for the currently supported version of this publication.

2. Heather M. Janney, county Extension director and Extension agent II, MS, UF/IFAS Extension Columbia County, Lake City, FL 32055.

The Institute of Food and Agricultural Sciences (IFAS) is an Equal Opportunity Institution authorized to provide research, educational information and other services

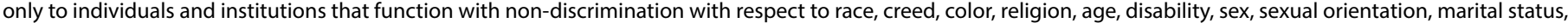
national origin, political opinions or affiliations. For more information on obtaining other UF/IFAS Extension publications, contact your county's UF/IFAS Extension office. U.S. Department of Agriculture, UF/IFAS Extension Service, University of Florida, IFAS, Florida A \& M University Cooperative Extension Program, and Boards of County Commissioners Cooperating. Nick T. Place, dean for UF/IFAS Extension. 


\section{A Newer, Less-Known Way That Helps Those with Impaired Vision}

Cut your piece of thread as previously instructed. Drape the thread across your palm with the ends hanging off your palm and just below your pointer finger. Pick up your needle and lay it across the thread so that the eye of the needle is facing up. Begin moving the needle across the thread, and eventually it will bunch up through the eye of the needle. The thread pulls through leaving the needle threaded.

This can take a lot of practice.

Experiment with threading a needle to decide which way is your favorite.

\section{Source}

Baker, M. (2004). Hand stitches. University of Kentucky Cooperative Extension: CT-MMB.002. Available at https://fcs-hes.ca.uky.edu/sites/fcs-hes.ca.uky.edu/files/ ct-mmb-002.pdf

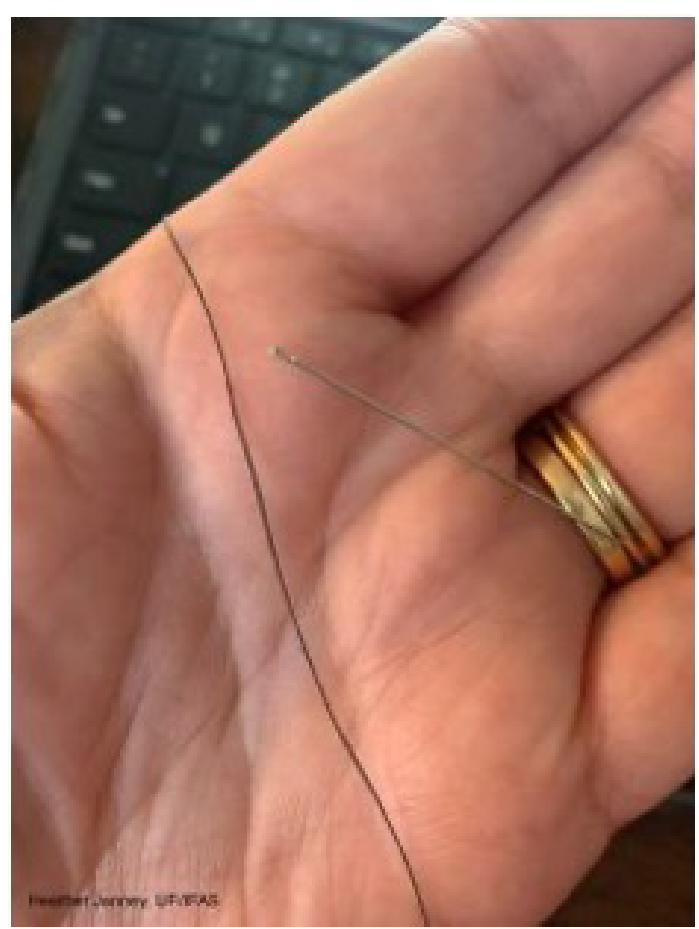

Figure 3. Drape the thread across your palm. Credits: Heather Janney, UF/IFAS 